\title{
Peran Keilmuan Endokrinologi Reproduksi dan Infertilitas terhadap Perlindungan Kesehatan Reproduksi Perempuan*
}

\author{
Andon Hestiantoro \\ Departemen Obstetri dan Ginekologi \\ Fakultas Kedokteran Universitas Indonesia - RS dr. Cipto Mangunkusumo, Jakarta \\ Penulis korespondensi: hestiantoro@gmail.com \\ Disetujui: 20 Oktober 2021 \\ https://doi.org/10.23886/ejki.9.78.162
}

\section{Pendahuluan}

Indonesia saat ini masih berjuang menghadapi masalah komplikasi kehamilan dan persalinan yang sangat rumit. Angka kematian ibu melahirkan berkisar 300 per 100.000 kelahiran hidup dan merupakan angka kematian ibu tertinggi di ASEAN. Segala upaya telah dicurahkan melalui berbagai program kesehatan baik pemerintah maupun swasta dengan harapan dapat menurunkan angka kematian ibu bersalin menjadi 183 per 100.000 kelahiran hidup. Masalah lain yang banyak dijumpai adalah tingginya prevalensi komplikasi kehamilan seperti preeklamsia $(15 \%)$, persalinan preterm $(29,5 \%)$, pertumbuhan janin terhambat/PJT $(6,2 \%)$, dan diabetes melitus (DM) dalam kehamilan $(1,9-3,6 \%){ }^{1}$

Upaya menurunkan kejadian komplikasi pada ibu hamil, kematian ibu hamil, dan bersalin tidak mudah selama pendekatannya hanya berfokus pada tata laksana di hilir atau tata laksana diberikan pada saat perempuan telah hamil. Oleh karena itu untuk mengatasi masalah ibu hamil seluruh daya upaya harus difokuskan di hulu.

Komplikasi kehamilan, kematian ibu hamil, dan bersalin, berkaitan erat dengan kondisi perempuan sebelum hamil. Terdapat indikator kesehatan yang menunjukkan status kesehatan remaja putri dan perempuan usia reproduksi sebelum hamil yang tidak baik. Pada riset kesehatan dasar (riskesdas) 2013, sebanyak $37,1 \%$ remaja putri mengidap anemia. Angka anemia tersebut meningkat menjadi $48,9 \%$ pada riskesdas $2018 .{ }^{1}$

Pada riskesdas 2018, proporsi kurang energi kronik pada perempuan usia subur sekitar 14,5$17,3 \%$. Indikator kesehatan lain yang berkaitan dengan menurunnya status kesehatan perempuan usia reproduksi adalah peningkatan proporsi berat badan lebih $(13,6 \%)$ dan obesitas $(21,8 \%)$ pada populasi dewasa. Kondisi tersebut sejalan dengan peningkatan proporsi obesitas sentral pada usia $>15$ tahun sebesar $31 \%$. Status kesehatan prakehamilan remaja putri dan perempuan usia reproduksi yang tidak baik, memiliki korelasi positif kuat dengan peningkatan kejadian komplikasi kehamilan dan kematian pada ibu hamil dan bersalin. ${ }^{1}$

\section{Sindrom Ovarium Polikistik}

Terdapat sindrom yang memiliki hubungan baik langsung maupun tidak langsung dengan status kesehatan perempuan yang telah disampaikan diatas, yaitu sindrom ovarium polikistik (SOPK). SOPK adalah kelainan endokrinopati yang paling sering dijumpai pada remaja putri dan perempuan usia reproduksi dengan angka kejadian bervariasi yaitu $1,8 \%-15 \%$. SOPK ditandai dengan gangguan siklus haid, gangguan kesuburan, ovarium polikistik pada pemeriksaan ultrasonografi (USG) yang dapat disertai dengan temuan klinis atau laboratoris yang berhubungan dengan peningkatan produksi androgen khususnya testosteron. Di Indonesia sindrom yang diderita perempuan terutama pada usia reproduksi meningkat dari tahun ke tahun.

SOPK tidak terbatas pada masalah reproduksi, tetapi mencakup masalah endokrin dan metabolik. Implikasi jangka panjang SOPK terkait dengan aspek reproduksi, fertilitas, sindrom metabolic, dan komplikasi kardiovaskular. Gangguan metabolisme gula dan lipid, kondisi inflamasi sistemik kronik, gangguan integritas vaskular, hipertensi, dan stres oksidatif diduga menimbulkan komorbiditas lain dan komplikasi kardiovaskular pada pasien SOPK. ${ }^{2}$

SOPK memiliki spektrum manifestasi klinis yang luas yaitu gangguan siklus menstruasi (oligomenorea atau amenorea); gejala hiperandrogenismeseperti hirsutisme, akne vulgaris, alopesia androgenik (ditandai dengan semakin mundurnya hairline dan kebotakan di bagian tengah kepala); resistensi insulin (ditandai dengan gangguan metabolisme glukosa, timbulnya 
akantosis nigrikans); infertilitas; dan kelainan morfologi ovarium polikistik yang dinilai dengan USG. Onset gejala SOPK umumnya pada fase perimenarche, yaitu saat perempuan berusia kurang lebih 16 tahun. Karena gejalanya sangat bervariasi, lebih dari $70 \%$ kasus SOPK tidak terdiagnosis di fasilitas kesehatan tingkat primer. Dua gejala yang paling sering menjadi penyebab penderita SOPK mencari pertolongan medis ke dokter ialah gangguan siklus menstruasi $(85-90 \%$ mengalami oligomenorea dan 30-40\% mengalami amenorea) dan infertilitas (90-95\%). ${ }^{2,3}$

\section{Etiopatogenesis SOPK}

SOPK merupakan sindrom kompleks dan etiologi maupun patogenesisnya belum dipahami sepenuhnya. Sebagai kelainan multifaktorial, SOPK terjadi akibat interaksi kompleks antara predisposisi genetik tertentu dan faktor lingkungan. Faktor lingkungan dapat bersifat kongenital (contoh: paparan androgen in utero secara berlebihan dan nutrisi prenatal), maupun didapat (contoh: obesitas, gaya hidup tidak sehat, pola nutrisi yang kurang baik).

\section{Faktor Genetik yang Diturunkan}

Kasus SOPK familial diturunkan secara autosomal dominan. Ibu yang menderita SOPK diduga menjadi salah satu faktor risiko timbulnya SOPK pada anak perempuannya. Anak yang terlahir dari ibu SOPK memiliki kadar serum $\mathrm{AMH}$ lebih tinggi pada masa bayi dan anak usia dini (early childhood). Anak-anak tersebut juga memiliki kadar dehidro-epiandrosteron sulfat (DHEAS) yang lebih tinggi pada masa peripubertas dan kadar testosteron basal yang lebih tinggi pada masa perimenarche..$^{2,3}$

Morfologi ovarium polikistik (polycystic ovarian morphology/PCOM) diturunkan secara autosomal dominan. Remaja dengan PCOM umumnya dilahirkan dari ibu dengan SOPK atau ayah dengan sindrom metabolik. Meskipun demikian, hanya sebagian anak perempuan dengan PCOM menunjukkan tanda atau gejala disfungsi steroidogenesis. Anakanak perempuan dengan PCOM yang disertai gangguan pembentukan hormon steroid biasanya memiliki risiko tinggi untuk mengalami SOPK di kemudian hari, terutama jika terjadi peningkatan berat badan yang berlebihan..$^{2,3}$

\section{Peran Kehidupan in Utero terhadap Kejadian SOPK}

Terdapat dua kondisi kehidupan in utero yang memiliki kontribusi bermakna terhadap timbulnya SOPK yaitu virilisasi kongenital dan faktor nutrisi intrauterin

Virilisasi kongenital. Penelitian eksperimental pada hewan coba menunjukkan bahwa androgenisasi kongenital atau pajanan terhadap androgen dosis tinggi selama masa kehamilan meningkatkan risiko SOPK. Janin kera yang terpajan androgen dosis tinggi selama kehamilan menunjukkan tanda dan gejala SOPK pada masa dewasa, seperti hiperandrogenisme ovarium dan adrenal, oligomenorea, morfologi ovarium polikistik, serta peningkatan kadar luteinizing hormone (LH) akibat inhibisi umpan balik negatif LH oleh progesteron. Kera juga mengalami obesitas sentral, resistensi insulin, gangguan toleransi glukosa, dan dislipidemia. Hal tersebut secara tidak langsung menyiratkan peran penting pemrograman epigenetik intrauterin terhadap perkembangan post-natal dari suatu kelainan atau penyakit. Pajanan androgen yang berlebihan tersebut sangat mungkin berasal dari ovarium janin itu sendiri, karena androgen dari ibu akan diubah menjadi estrogen oleh enzim aromatase yang dihasilkan plasenta. ${ }^{2,3}$

Faktor nutrisi intrauterin. Banyak bukti ilmiah menunjukkan bahwa kondisi kekurangan nutrisi (malnutrisi) selama masa prenatal memiliki korelasi erat dengan kejadian sindrom metabolik dan penyakit kardiovaskular di kemudian hari. Saat ini, beberapa konsensus mempercayai bahwa berat lahir rendah (BLR) atau pertumbuhan janin terhambat (PJT) merupakan salah satu faktor predisposisi terjadinya SOPK dan resistensi insulin pada neonatus tersebut. Berbagai faktor yang menyebabkan terganggunya unit feto-plasenta dan mengakibatkan terhambatnya pertumbuhan janin merupakan faktor risiko SOPK, seperti pola diet tidak seimbang, gaya hidup sedenter, merokok, konsumsi alkohol, maupun adanya komorbiditas pada ibu (hipertensi, resistensi insulin, obesitas, dan lain-lain). ${ }^{2,3}$

\section{Pengaruh Lingkungan Postnatal terhadap Kejadian SOPK}

Lingkungan postnatal berperan penting pada kejadian SOPK, terutama bagi individu dengan predisposisi genetik yang menunjang. Beberapa kondisi post-natal yang berkatan erat dengan SOPK sebagai berikut. 


\section{Resistensi Insulin}

Resistensi insulin dan hiperinsulinemia adalah faktor kunci patogenesis gangguan ovulasi dan hiperandrogenisme pada SOPK. Siklus haid tanpa ovulasi lebih sering ditemukan pada penderita SOPK yang disertai resistensi insulin. Kondisi resistensi insulin menyebabkan perubahan pada metabolisme dan sintesis hormon androgen, baik oleh ovarium maupun kelenjar adrenal. Meskipun lebih sering pada obesitas, penderita SOPK dengan berat badan normal juga tidak terhindar dari kemungkinan resistensi insulin.

Resistensi insulin yang disertai tingginya kadar insulin dalam darah akan meningkatkan aktivitas aksis hipofisis - pituitari-gonad (HPG) dan hipofisis - pituitari - adrenal (HPA), yang selanjutnya menstimulasi aktivitas enzim 17 $\alpha$-hidroksilase. Enzim tersebut berperan dalam mengonversi senyawa $17(\mathrm{OH})$-pregnenolon menjadi DHEAS, sehingga kadar androgen meningkat. Selain itu, hiperinsulinemia juga menurunkan produksi sex hormone binding globulin (SHBG) di dalam hati sehingga kadar testosteron bebas di dalam darah semakin meningkat. ${ }^{3-5}$

Penyebab resistensi insulin pada pasien SOPK sangat bervariasi, salah satunya adalah akumulasi lemak tubuh yang berlebih dan obesitas. Pada individu obesitas, jaringan adiposa melepas lebih banyak asam lemak yang tidak teresterifikasi (non-esterified fatty acidNEFA), gliserol, hormon, sitokin pro-inflamasi, dan faktor lain yang berperan dalam pembentukan kondisi resistensi insulin. Meningkatnya pelepasan senyawa tersebut berakibat pada teraktivasinya kaskade serin/ treonin kinase sehingga terjadi fosforilasi serin/ treonin pada insulin receptor substrate (IRS)-1 dan IRS-2, serta berkurangnya kemampuan kedua substrat reseptor tersebut dalam mengaktivasi sinyal $\mathrm{PI}(3) \mathrm{K}$ di otot.

Hubungan androgen dan insulin pada SOPK bersifat dua arah. Kondisi hiperandrogenisme dapat memperparah resistensi insulin pada perempuan dengan SOPK. Hal tersebut sesuai dengan hasil penelitian yang menyatakan penggunaan pil kontrasepsi yang mengandung progesteron "androgenik" menurunkan sensitivitas jaringan terhadap insulin dan memperburuk toleransi glukosa.

Manifestasi hiperandrogenisme pada penderita SOPK sangat bervariasi yaitu hirsutisme, akne vulgaris, alopesia androgenik, dermatitis seboroik, dan manifestasi resistensi insulin seperti akantosis nigrikans. Hirsutisme adalah pertumbuhan rambut secara berlebih di area predileksi yang umumnya ditumbuhi rambut pada laki-laki, seperti wajah, dada, dan punggung. Untuk menentukan apakah seseorang mengalami hirsutisme atau tidak, dapat digunakan kriteria Ferriman Gallwey Score (FGS), yaitu nilai $>8$ dianggap hirsutisme. Fenotipe SOPK dengan tampilan hirsutisme sesuai FGS 8 sangat jarang dijumpai. Saat ini digunakan FGS 5 atau lebih sebagai penentuan hirsutisme pada subjek dengan SOPK.

\section{Hipersekresi LH pada SOPK}

Hormon lain yang berperan penting pada patogenesis dan patofisiologi SOPK adalah LH. Sebanyak 40-60\% penderita SOPK memiliki kadar LH yang lebih tinggi dibandingkan populasi sehat. Peningkatan sekresi LH diduga disebabkan defek neuroendokrin primer pada aksis HPG yang meningkatkan frekuensi dan amplitudo sekresi gonadotropin releasing hormone $(\mathrm{GnRH})$ di hipotalamus. ${ }^{2-4}$

Gangguan ovulasi pada penderita SOPK biasanya akibat peningkatan sekresi LH yang diikuti penurunan sekresi follicle stimulating hormone (FSH) dan ketidakseimbangan kedua hormon tersebut mengganggu proses folikulogenesis. FSH merupakan hormon vital pada proses folikulogenesis karena berperan pada proses maturasi folikel sampai diperoleh folikel dominan yang siap diovulasikan.

Pada kondisi resistensi insulin, hiperinsulinemia meningkatkan sekresi inhibin yang memiliki efek samping menekan produksi FSH. Bersama dengan hipersekresi $\mathrm{LH}$, penurunan kadar $\mathrm{FSH}$ menyebabkan terhentinya proses maturasi folikel dan luteinisasi prematur. Folikel yang tidak matur terakumulasi di ovarium, menghasilkan PCOM. ${ }^{3-5}$

\section{Kondisi Inflamasi Kronik Derajat Rendah}

Kondisi inflamasi kronik derajat rendah sering dijumpai pada subjek SOPK. Beberapa kondisi resistensi insulin, obesitas, akumulasi lemak tubuh berlebih, maupun distribusi lemak tubuh yang tidak ideal berpotensi meningkatkan sekresi sitokin proinflamasi seperti TNF- $\alpha$, IL-1, IL-6, dan C-reactive protein (CRP). Kondisi inflamasi kronik tidak hanya terjadi pada penderita SOPK, tetapi banyak ditemukan pada penyakit lain yang berhubungan dengan sindrom metabolik dan resistensi insulin. Dalam jangka panjang, kondisi inflamasi dapat menimbulkan komorbiditas dan atau komplikasi lain, seperti penyakit kardiovaskular. ${ }^{4}$ 


\section{Dysbiosis of Gut Microbiota (DOGMA) pada SOPK}

DOGMA atau disbiosis mikrobiota usus merupakan teori yang baru dikembangkan guna mempelajari peran mikrobiologi dalam patogenesis dan patofisiologi SOPK. Disbiosis mikrobiota usus dapat meningkatkan produksi androgen oleh sel theca ovarium dan mengganggu proses pembentukan folikel matur melalui inflamasi kronik derajat rendah dan resistensi insulin. Mikrobiota usus dan metabolitnya mampu meregulasi aktivitas kaskade inflamasi, sekresi brain-gut peptide dan proliferasi sel $\beta$ pankreas. Hal itu berimplikasi pada kondisi yang dapat muncul sebagai akibat ketidakseimbangan mikrobiota usus, seperti akumulasi lemak berlebih atau abnormal, resistensi insulin, dan hiperinsulinemia. ${ }^{4-6}$ Terdapat dua mekanisme utama pada teori DOGMA, yaitu:

1. Diet tinggi lemak dan gula memicu pertumbuhan bakteri patogen di usus (Enterococcus, Clostridia, E. coli, Proteus, Pseudomonas) dan menekan pertumbuhan bakteri "baik" (Bidifobacteria, Lactobacillus). Bakteri gram negatif tersebut memiliki lipopolisakarida (LPS) di permukaan dinding sel dan jika kadar dalam plasma darah meningkat, maka sel myeloid teraktivasi secara sistemik untuk memproduksi sitokin pro-inflamasi secara berlebih (IL-1 $\beta$, IL-6, TNF $\alpha$ ).

2. Diet tinggi lemak dan gula, serta rendah serat dapat meningkatkan permeabilitas mukosa usus terhadap berbagai substansi, salah satunya adalah kandungan LPS di permukaan sel bakteri tersebut. Jika LPS masuk ke sirkulasi sistemik (endotoksemia metabolik), maka terbentuk respons inflamasi sistemik dan aktivasi makrofag, yang berakhir pada terjadinya resistensi insulin.

\section{Diagnosis SOPK}

Diagnosis SOPK ditegakkan berdasarkan sejumlah kriteria. Salah satu kriteria yang banyak digunakan adalah kriteria Rotterdam tahun 2003. ${ }^{4}$ Berdasarkan kriteria tersebut, diagnosis SOPK ditegakkan jika terpenuhi setidaknya 2 dari 3 aspek berikut:

1. Tanda klinis atau biokimia hiperandrogenisme

2. Gangguan ovulasi kronik

3. Gambaran morfologi ovarium polikistik pada pemeriksaan USG

\section{Manfaat Hormon AMH dan Insulin sebagai Marka Diagnostik SOPK}

Terdapatdua hormon lain yang berperan penting pada SOPK, yaitu anti Mullerian hormone $(\mathrm{AMH})$ dan insulin. Nilai AMH menggambarkan kuantitas dan kualitas simpanan folikel di ovarium sehingga dapat digunakan sebagai penanda cadangan ovarium. Konsentrasi $\mathrm{AMH}$ merepresentasikan jumlah folikel antral pada pemeriksaan USG, kadar testosteron dan volume ovarium. Umumnya, terjadi peningkatan kadar AMH sampai 2-3 lipat pada penderita SOPK dibandingkan populasi normal. $\mathrm{AMH}$ dapat digunakan sebagai prediktor alternatif marka diagnostik SOPK dengan nilai titik potong $4,45 \mathrm{ng} / \mathrm{mL}$. Selain itu nilai potong AMH sebesar $8,58 \mathrm{ng} / \mathrm{mL}$ dapat digunakan sebagai marka diagnostik resistensi klomifen sitrat pada SOPK..$^{5-7}$

Resistensi insulin, sebagai faktor kunci dalam patofisiologi, juga berperan penting dalam diagnosis SOPK. Resistensi insulin banyak ditemukan pada individu obesitas, termasuk obesitas sentral. Karena resisten terhadap insulin, maka tubuh berusaha untuk mengkompensasi dengan meningkatkan produksi insulin sehingga terjadi hiperinsulinemia yang mencetuskan lipogenesis dan meningkatkan produksi asam lemak bebas. Resistensi insulin diperiksa dengan mengukur kadar gula serta insulin saat puasa dan pasca tes toleransi glukosa oral (TTGO). Baku emas pemeriksaan insulin adalah pemeriksaan klem euglikemik namun pemeriksaan tersebut sulit dilakukan sehingga digunakan pemeriksaan lain yaitu HOMA-IR dan QUICK1. Sama seperti FGS, nilai potong HOMA IR juga bervariasi pada masing-masing etnis. Dari penelitian Natadisastra didapatkan titik potong $10,1 \mathrm{IU} / \mathrm{ml}$ nisbah gula darah puasa per insulin puasa dengan sensitivitas $90,2 \%$ dan spesifisitas $90,9 \%$, nilai duga positif $87,8 \%$ dan nilai duga negatif $90,9 \%$, yang dapat digunakan sebagai kriteria minor diagnosis SOPK..$^{5-7}$

\section{SOPK dan Komplikasi Kehamilan}

Penderita SOPK memiliki risiko lebih tinggi untuk komplikasi tertentu selama hamil. Selain itu, bayi yang lahir dari ibu SOPK berisiko lebih tinggi untuk berada di unit perawatan intensif dalam waktu lama atau meninggal sebelum, selama, atau tepat setelah lahir. Sindrom metabolik dan peningkatan androgen meningkatkan risiko bahaya untuk kehidupan bayi baru lahir.

\section{Komplikasi Kehamilan yang Berkaitan dengan SOPK}

Penderita SOPK tiga kali lebih mungkin mengalami keguguran pada bulan-bulan awal kehamilan dibandingkan perempuan tanpa SOPK. 
Metformin dapat mengurangi risiko keguguran pada ibu hamil dengan SOPK namun, penelitian lain menyatakan metformin mengurangi risiko keguguran.

\section{Diabetes Melitus Gestasional}

Diabetes gestasional hanya dialami oleh ibu hamil. Penyakit tersebut dapat diobati dan jika dikendalikan, tidak menyebabkan masalah yang berarti bagi ibu atau janin; umumnya hilang setelah bayi lahir. Bayi yang ibunya menderita diabetes gestasional dapat berukuran sangat besar, kadar gula darah rendah, dan kesulitan bernapas. Penderita diabetes gestasional dan anak-anaknya berisiko lebih tinggi menderita DM tipe 2 di kemudian hari. $^{7-9}$

\section{Preeklamsia dan Eklamsia}

SOPK berkaitan dengan preeklamsia dan eklamsia. Peningkatan tekanan darah secaratibatiba setelah minggu ke-20 kehamilan, dapat memengaruhi ginjal, hati, dan otak ibu. Jika tidak ditangani dengan baik, preeklamsia dapat berubah menjadi eklampsia, yaitu kejang pada kehamilan dan persalinan. Eklamsia dapat menyebabkan kerusakan organ, kejang, bahkan kematian. Pengobatan utama adalah melahirkan bayi, bahkan prematur jika perlu. Ibu hamil dengan preeklamsia mungkin memerlukan persalinan dengan bedah caesar yang dapat menambah risiko bagi ibu dan bayi. ${ }^{7-9}$

\section{Persalinan Preterm}

Bayi dianggap "prematur" jika dilahirkan sebelum 37 minggu kehamilan. Bayi prematur berisiko mengalami banyak masalah kesehatan, baik setelah lahir maupun di kemudian hari, dan beberapa masalah bahkan dapat serius. Mengingat SOPK dapat meningkatkan angka kematian ibu hamil dan bersalin, serta komplikasi kehamilan, maka tata laksana SOPK yang tepat sangat diperlukan untuk memberikan perlindungan kesehatan reproduksi perempuan. ${ }^{7-9}$

\section{Edukasi dan Modifikasi Gaya Hidup}

Pada SOPK, modifikasi gaya hidup merupakan terapi lini pertama, di dalamnya tercakup aktivitas fisik dan intervensi diet. Terapi aktivitas fisik dan intervensi diet bersifat individual dan disesuaikan dengan kebutuhan dasar individu penderita SOPK. Melalui modifikasi diet dan aktivitas fisik, diharapkan profil hormonal dan metabolik membaik. Pada penderita SOPK dengan obesitas, modifikasi gaya hidup diharapkan menurunkan berat badan dan kadar lemak tubuh, sehingga terjadi penurunan kondisi inflamasi kronik dan perbaikan sensitivitas insulin. ${ }^{12-14}$

\section{Diet pada Subjek SOPK}

Obesitas merupakan kondisi komorbid metabolik yang paling sering pada penderita SOPK. Data RSCM tahun 2008 menunjukkan sebanyak $73 \%$ penderita SOPK memiliki indeks massa tubuh lebih dari $25 \mathrm{~kg} / \mathrm{m}^{2}$, yang diklasifikasikan sebagai obesitas menurut kriteria WHO - Asia Pasifik. Pada penderita SOPK, penurunan berat badan 2$5 \%$ terbukti memperbaiki fungsi metabolik dan reproduksi, yang ditandai dengan peningkatan sintesis SHBG, penurunan kadar androgen bebas, dan perbaikan fungsi ovulasi. Secara umum, target penurunan berat badan yang dikehendaki adalah $5-10 \%$ dalam 6 bulan - 1 tahun pertama. Untuk mencapai tujuan tersebut, dilakukan pengurangan asupan kalori harian 500 - 1000 kkal dengan memperhatikan komposisi makanan agar tetap bergizi seimbang. Komposisi seimbang adalah $50 \%$ karbohidrat, $20 \%$ protein, dan $30 \%$ lemak (10\% lemak jenuh, $10 \%$ lemak polyunsaturated/ PUFA, dan $10 \%$ lemak monounsaturated/ MUFA). ${ }^{10-12}$ Pembatasan asupan kalori tidak dapat dilakukan secara ekstrem sampai di bawah 1200 kkal, karena menyebabkan yoyo effect, yaitu pada awalnya berat badan menurun signifikan dengan cepat, tetapi hanya berlangsung sementara. Saat tubuh kita mencapai fase plateau, berat badan meningkat kembali. Idealnya, asupan kalori dibagi menjadi beberapa kali makan, yaitu 3 kali makan berat (sarapan, makan siang, dan makan malam) diselingi dengan $2-3$ kali snack. ${ }^{12-14}$

\section{Diet Karbohidrat}

Diet karbohidrat yang direkomendasikan pada penderita SOPK adalah diet gula dengan indeks glikemik (IG) rendah. Karbohidrat dengan IG rendah dapat meningkatkan sensitivitas insulin dan meningkatkan konsentrasi kolesterol HDL. Sebaliknya, diet dengan IG tinggi dapat menurunkan sensitivitas insulin dan meningkatkan risiko sindrom metabolik, DM tipe 2, dan penyakit kardiovaskular. Dampak jangka panjang diet rendah IG adalah penurunan risiko kejadian kanker endometrium. Diet karbohidrat IG rendah membantu mengembalikan regularitas siklus menstruasi pada $95 \%$ perempuan. ${ }^{12,13}$

\section{Diet Protein}

Diet tinggi protein (protein $>40 \%$, lemak 
$30 \%$ dan karbohidrat $<30 \%$ ) bermanfaat untuk menurunkan berat badan dan kadar lemak tubuh. Diet tersebut juga bermanfaat untuk mengurangi lingkar pinggang dan kadar insulin darah. Namun, tidak terdapat perbedaan bermakna dalam kadar testosteron, SHBG, dan lipid darah antara kelompok yang menjalani diet tinggi protein dan diet protein standar. ${ }^{12,13}$

Pedoman diet terbaru merekomendasikan bahwa konsumsi protein harian seharusnya tidak melebih $20 \%$ angka kebutuhan gizi. Diet $1.400 \mathrm{kkal} /$ hari, terlepas dari kandungan proteinnya tinggi atau rendah, menurunkan berat badan, kadar trigliserida plasma, kolesterol total, dan insulin yang hampir sama. Diet tinggi protein juga harus diterapkan dengan hati-hati karena berpotensi mengganggu fungsi ginjal dan kepadatan massa tulang. ${ }^{13,14}$

\section{Diet Lemak}

Lemak adalah komponen makronutrien dengan kandungan energi paling tinggi dibandingkan karbohidrat dan protein. Kelebihan energi dalam tubuh disimpan dalam bentuk lemak dan tubuh manusia memiliki kemampuan yang hampir tidak terbatas untuk menyimpan lemak. Kadar lemak tinggi menyebabkan resistensi insulin dan hiperinsulinemia. Idealnya, konsumsi lemak harian tidak melebihi $30 \%$ angka kebutuhan gizi harian, dengan kadar lemak jenuh maksimal 10\%.

Konsumsi PUFA dan MUFA yang diwakili kacang almond dan dapat meningkatkan kadar adiponektin dan SHBG, serta menurunkan kadar kolesterol LDL, apoB, dan FAI. Meskipun demikian, tidak ada penurunan kadar sitokin pro-inflamasi dan peningkatan sensitivitas insulin. Hal tersebut menunjukkan konsumsi lemak tidak jenuh pada penderita SOPK dapat memperbaiki profil lipid dan hormon, serta mengurangi risiko penyakit kardiovaskular. ${ }^{13,14}$

\section{Diet Tinggi Serat}

Penderita SOPK direkomendasikan untuk mengonsumsi diet tinggi serat karena membantu menurunkan IMT dan memperbaiki profil androgen. Hasil uji klinis terandomisasi menunjukkan diet tinggi serat pada perempuan obesitas bermanfaat menurunkan kadar DHEA, estradiol, serta testosteron sehingga terjadi perbaikan profil hormon. Penderita SOPK yang mengonsumsi diet tinggi serat mengalami penurunan kadar testosteron postprandial yang lebih cepat dibandingkan yang mengonsumsi diet tinggi lemak. Penurunan kadar testosteron postprandial terjadi akibat peningkatan aliran darah hati dan ekstraksi steroid di hati setelah makan. Konsumsi diet tinggi lemak memperlambat aliran arteri dan vena portal mesenterika, sehingga waktu untuk menyerap dan memetabolisme nutrisi lebih lambat. ${ }^{15}$

\section{Vitamin D}

Defisiensi vitamin B banyak dipelajari sebagai salah satu faktor yang berperan penting dalam patogenesis SOPK. Sebanyak $67-85 \%$ penderita SOPK memiliki kadar serum 25-hidroksi vitamin D (25-OHD) lebih rendah dari $20 \mathrm{ng} / \mathrm{mL}$. Defisiensi vitamin B menurunkan sekresi insulin, jumlah reseptor insulin, dan meningkatkan kadar hormon PTH sehingga terjadi resistensi insulin. Defisiensi vitamin D dapat menurunkan konsentrasi SHBG dan meningkatkan sekresi testosteron sehingga terjadi hiperandrogenisme. Defisiensi vitamin D menyebabkan disregulasi kalsium sehingga maturasi folikel terhambat dan berdampak pada abnormalitas siklus menstruasi serta infertilitas karena siklus haid anovulatoris. Defisiensi vitamin $D$ berhubungan erat dengan peningkatan HOMAIR, abnormalitas profil lipid, gangguan metabolisme glukosa, dan peningkatan penanda inflamasi seperti CRP. ${ }^{14,15}$

\section{Penutup}

SOPK merupakan penyakit endokrinopati yang paling sering dialami oleh perempuan usia reproduksi. Sindrom tersebut berkaitan erat dengan pola hidup sedenter, status gizi tidak baik, sindrom metabolik, resistensi insulin, dan reaksi inflamasi kronik derajat rendah. Jika tidak dikelola dengan baik maka SOPK dapat meningkatkan kejadian komplikasi kehamilan dan menjadi penyebab peningkatan angka kematian ibu hamil dan bersalin. Pemahaman karakteristik klinis SOPK dan penguasaan marka diagnostik tentang SOPK, yang dilanjutkan dengan tata laksana spesifik, diharapkan dapat menjadi cara tepat menurunkan komplikasi kehamilan, kematian ibu hamil dan bersalin melalui pendekatan terapi dini, presisi dan personal.

*Naskah ini Merupakan Ringkasan Pidato Pengukuhan Guru Besar Prof. Dr. dr. Andon Hestiantoro, Sp.OG(K)-FER, M.P.H, di Jakarta, aula FKUI, 3 Juli 2021

\section{Daftar Pustaka}

1. Badan Penelitian dan Pengembangan Kesehatan Kementerian Kesehatan RI. Riset Kesehatan Dasar 2018. Jakarta: Kementerian Kesehatan RI; 2018. 
2. Teede HJ, Misso ML, Costello MF, Dokras A, Laven J, Moran L, Piltonen T, Norman RJ, International PCOS Network. Recommendations from the international evidence-based guideline for the assessment and management of polycystic ovary syndrome. Hum Reprod. 2018;33:1612-8. doi: 10.1016/j. fertnstert.2018.05.004.

3. Rosenfield RL, Ehrmann DA. The pathogenesis of polycystic ovary syndrome (PCOS): the hypothesis of PCOS as functional ovarian hyperandrogenism revisited. Endocr Rev. 2016;37:467-520. doi: 10.1210/ er.2015-1104.

4. Wawrzkiewics-Jalowiecka A, Kowalczyk K, Trybek $P$, Jarosz T, Radosz P, Setlak M, et al. In search of new therapeutics-molecular aspects of the PCOS pathophysiology: genetics, hormones, metabolism and beyond. Int J Mol Sci. 2020;21:7054. doi: 10.3390/ ijms21197054.

5. Yu HF, Chen HS, Rao DP, Gong J. Association between polycystic ovary syndrome and the risk pregnancy complications: A PRISMA-complaint systematic review and meta-analysis. Medicine. 2016;95:e4863. doi: 10.1097/MD.0000000000004863.

6. Palomba S, Santagni S, Falbo A, La Sala GB. Complications and challenges associated with polycystic ovary syndrome : current perspectives. Int J Womens Health. 2015;7:745 -63. doi: 10.2147/IJWH.S70314.

7. Bellver J, Taberneo-Rodriguez L, Robles A, Munoz E, Martinez F, Landeraa J, et al. Group of Interest in Reproductive Endocrinology (GIER) of the Spanish Fertility Society (SEF). Polycystic ovary syndrome throughout a woman's life. J Assist Reprod Genet. 2018;35:25 - 39. doi: 10.1007/s10815-017-1047-7.

8. Costello MF, Misso ML, Balen A, Boyle J, Devoto L, Garad $\mathrm{RM}$, et al. Evidence summaries and recommendations from the international evidence-based guideline for the assessment and management of polycystic ovary syndrome: assessment and treatment of infertility. Hum Reprod Open 2019;2019:hoy021. doi:10.1093/hropen/ hoy021
9. Zhang J, Bao Y, Zhou Xu, Zheng L. Polycystic ovary syndrome and mitochondrial dysfunction. Reprod Biol Endocrinol. 2019;17:67. doi: 10.1186/s12958-0190509-4.

10. Lin AW, Kazemi M, Jarett BY, Brink HV, Hoeger KM, Spandorfer SD, et al. Dietary and physical activitty behaviors in women with polycystic ovary syndrome per the new international evidence-based guideline. Nutrients. 2019;11:2711. doi: 10.3390/nu11112711.

11. Paris VR, Solon-Biet SM, Senior AM, Edwards MC, Desai R. Tedla N, et al. Defining the impact of dietary macronutrient balance on PCOS traits. Nat Commun. 2020;11:5262. doi: 10.1038/s41467-020-19003-5.

12. Shele G, Genkill J, Speelman D. A systematic review of the effects of exercise on hormones in women with polycystic ovary syndrome. J Funct Morphol Kinesol. 2020;5:35. doi: 10.3390/jfmk5020035.

13. Kite C, Lahart IM, Afzal I, Broom DR, Randeva H, Kyrou L, et al. Exercise, or exercise and diet for the management of polycystic ovary syndrome: a systematic review and meta-analysis. Syst Rev. 2019;8:51. doi: 10.1186/s13643-019-0962-3.

14. Scott D, Harrison CL, Hutchison S, de Courten B, Stepto NK. Exploring factors related to changes in body composition, insulin sensivity and aerobic capacity in response to a 12-week exercise intervention in overweight and obese women with and without polycystic ovary syndrome. PLoS One. 2017;12:e0182412. doi: 10.1371/journal. pone.0182412.

15. Szczuko M, Szydlowska I, Nawrocka-Rutkowska J. A properly balanced reduction diet and/or supplementation solve the problem with the deficiency of these vitamins soluble in water in patients with PCOS. Nutrients. 2021;13:746. doi: 10.3390/nu13030746. 